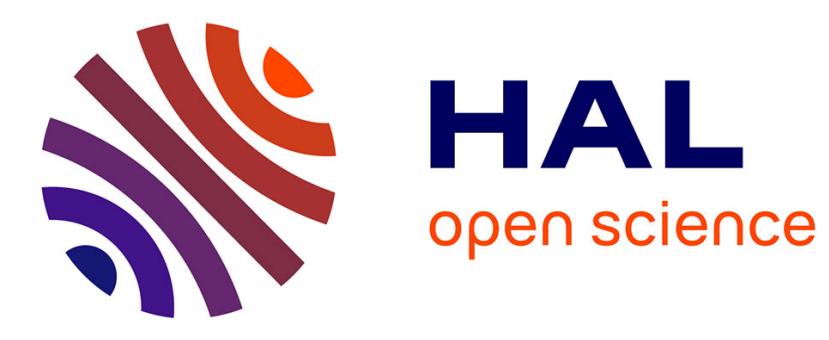

\title{
Plant traits related to nitrogen uptake influence plant-microbe competition
}

Delphine Moreau, Barbara Pivato, David Bru, Hugues Busset, Florence Deau, Céline Faivre, Annick Matejicek, Florence Strbik, Laurent L. Philippot, Christophe Mougel

\section{To cite this version:}

Delphine Moreau, Barbara Pivato, David Bru, Hugues Busset, Florence Deau, et al.. Plant traits related to nitrogen uptake influence plant-microbe competition. Ecology, 2015, 96 (8), pp.2300-2310. 10.1890/14-1761.1. hal-02637764

\section{HAL Id: hal-02637764 https://hal.inrae.fr/hal-02637764}

Submitted on 28 May 2020

HAL is a multi-disciplinary open access archive for the deposit and dissemination of scientific research documents, whether they are published or not. The documents may come from teaching and research institutions in France or abroad, or from public or private research centers.
L'archive ouverte pluridisciplinaire HAL, est destinée au dépôt et à la diffusion de documents scientifiques de niveau recherche, publiés ou non, émanant des établissements d'enseignement et de recherche français ou étrangers, des laboratoires publics ou privés.

$$
\text { Copyright }
$$




\title{
Plant traits related to nitrogen uptake influence plant- microbe competition
}

\author{
Delphine Moreau, Barbara Pivato, David Bru, Hugues Busset, Florence Deau, Céline Faivre, \\ Annick Matejicek, Florence Strbik, Laurent Philippot, ${ }^{1}$ and Christophe Mougel ${ }^{2}$
}

INRA, UMR1347 Agroécologie, BP 86510, F-21000 Dijon, France

\begin{abstract}
Plant species are important drivers of soil microbial communities. However, how plant functional traits are shaping these communities has received less attention though linking plant and microbial traits is crucial for better understanding plant-microbe interactions. Our objective was to determine how plant-microbe interactions were affected by plant traits. Specifically we analyzed how interactions between plant species and microbes involved in nitrogen cycling were affected by plant traits related to nitrogen nutrition in interaction with soil nitrogen availability. Eleven plant species, selected along an oligotrophicnitrophilic gradient, were grown individually in a nitrogen-poor soil with two levels of nitrate availability. Plant traits for both carbon and nitrogen nutrition were measured and the genetic structure and abundance of rhizosphere microbial communities, in particular the ammonia oxidizer and nitrate reducer guilds, were analyzed. The structure of the bacterial community in the rhizosphere differed significantly between plant species and these differences depended on nitrogen availability. The results suggest that the rate of nitrogen uptake per unit of root biomass and per day is a key plant trait, explaining why the effect of nitrogen availability on the structure of the bacterial community depends on the plant species. We also showed that the abundance of nitrate reducing bacteria always decreased with increasing nitrogen uptake per unit of root biomass per day, indicating that there was competition for nitrate between plants and nitrate reducing bacteria. This study demonstrates that nitrate-reducing microorganisms may be adversely affected by plants with a high nitrogen uptake rate. Our work puts forward the role of traits related to nitrogen in plant-microbe interactions, whereas carbon is commonly considered as the main driver. It also suggests that plant traits related to ecophysiological processes, such as nitrogen uptake rates, are more relevant for understanding plant-microbe interactions than composite traits, such as nitrophily, which are related to a number of ecophysiological processes.
\end{abstract}

Key words: competition; functional trait; greenhouse experiment; nitrate; nitrogen; oligotrophicnitrophilic gradient; plant-microbe interactions; rhizosphere.

\section{INTRODUCTION}

Microorganisms living in the rhizosphere, the area of soil that immediately surrounds and is affected by plant roots, have long been recognized to profoundly affect plant nutrition and health (Hiltner 1904, Hartmann et al. 2008). Recent studies have shown that belowground microbial communities are also important drivers of plant biodiversity and productivity (Van Der Heijden et al. 2008). It has been shown that the species composition of the arbuscular mycorrhizal fungal community has a significant effect on plant biomass and that plant diversity increases with increasing fungal species richness (van der Heijden et al. 1998). On the other hand,

Manuscript received 15 September 2014; revised 7 January 2015; accepted 28 January 2015. Corresponding Editor: J. B. Yavitt.

1 Corresponding author.

E-mail: laurent.philippot@dijon.inra.fr.

2 Present address: INRA, UMR1349 IGEPP, F-35653 Le Rheu, France. several properties of the rhizosphere soil are modified during plant growth (Philippot et al. 2013) and therefore plants can, in turn, influence soil microbial diversity and activity (Aira et al. 2010, Orwin et al. 2010, de Vries et al. 2012, Zancarini et al. 2012, Zancarini et al. 2013).

While most studies have focused on the effect that different plant species have on microbial community composition (Yin et al. 2012, Tsiknia et al. 2013), less attention has been paid to plant functional traits. Functional traits are morphological, physiological, or phenological properties that are measurable at the individual level (Violle et al. 2007). Pioneer studies were based on the comparison of plant species from different functional types, i.e., monocotyledonous, dicotyledonous, or legume species (Bezemer et al. 2006, Bremer et al. 2007, De Deyn et al. 2009), or of plant species from different habitats (Bouasria et al. 2012). For example, by studying grassland species with different growth strategies, Orwin et al. (2010) showed that bacterialdominated soil microbial communities were associated with plant species with low root $\mathrm{N}$ content. Community- 
TABLE 1. Studied species, their EPPO code, classification (monocotyledon, M; dicotyledon, D; legume, L), Ellenberg's indicator value describing the $\mathrm{N}$ richness of their preferred habitat, and their calculated nitrophily index describing the response of plant growth to added soil $\mathrm{N}$.

\begin{tabular}{|c|c|c|c|c|}
\hline $\begin{array}{l}\text { Species (cultivar and lines for } \\
\text { crop and model species) }\end{array}$ & $\begin{array}{l}\text { EPPO } \\
\text { codet }\end{array}$ & Class & $\mathrm{N}$ indicator & $\begin{array}{l}\text { Nitrophily } \\
\text { index }\end{array}$ \\
\hline Teucrium botrys $\mathrm{L}$. & TEUBO & $\mathrm{D}$ & 2 & 10 \\
\hline Bromus hordeaceus L. & BROMO & M & 3 & 16 \\
\hline Geranium molle L. & GERMO & $\mathrm{D}$ & 4 & 21 \\
\hline Alopecurus myosuroides Huds. & ALOMY & $\mathrm{M}$ & 6 & 34 \\
\hline Echinochloa crus-galli (L.) Beauv. & ECHCG & $\mathrm{M}$ & 8 & 13 \\
\hline Matricaria perforata Mérat. & MATIN & $\mathrm{D}$ & 8 & 38 \\
\hline Centaurea cyanus $\mathrm{L}$. & CENCY & $\mathrm{D}$ & NA & 18 \\
\hline Brassica napus L. (cv Kadore) & BRSNN & $\mathrm{D}$ & NA & 29 \\
\hline Triticum aestivum L. (cv Caphorn) & TRZAS & M & NA & 26 \\
\hline Brachypodium distachyon (L.) P.Beauv. & BRCDI & M & NA & 8 \\
\hline Medicago truncatula Gaertn. (line A17) & MEDTR & $\mathrm{M}, \mathrm{L}$ & NA & 2 \\
\hline
\end{tabular}

Notes: The Ellenberg (1974) indicator value ranges from 0 to 9 , representing N-poor to N-rich soils. The nitrophily index increases with increasing plant species response to soil $\mathrm{N}$ availability. NA indicates $\mathrm{N}$ indicator values that are not available.

$\dagger$ European and Mediterranean Plant Protection Organization: https://www.eppo.int/ DATABASES/eppt/eppt.htm

† Ellenberg (1974).

weighted means of plant functional traits were also found to explain soil microbial community composition at a landscape scale (de Vries et al. 2012). As traits describe how organisms interact with their biotic and abiotic environment, the importance of using plant traits to understand the differential plant species responses to plant-soil feedbacks has been demonstrated (Baxendale et al. 2014). Further, plant functional traits involved in plant-microbial interactions have been summarized in several comprehensive reviews (Mendes et al. 2013, Philippot et al. 2013).

As soil microorganisms are usually limited by the supply of easily decomposed carbon (Hodge et al. 2000), the carbon released by the plant in the rhizosphere is commonly considered as one of the main drivers of plant-microbe interactions (Berg and Smalla 2009). However, nitrogen $(\mathrm{N})$ can also play an important role as it is usually limiting to plant growth and conversion between the different forms of $\mathrm{N}$ depends on processes performed by soil microorganisms (Vitousek and Howarth 1991, Frank and Groffman 2009). Thus, it has been shown that invasion by plants can alter $\mathrm{N}$ cycling by increasing the abundance and activity of ammonia-oxidizing soil microbial communities (Hawkes et al. 2005). Some plants are also able to inhibit nitrifying microorganisms, which in turn reduces the amount of $\mathrm{N}$ lost through leaching and denitrification (Subbarao et al. 2012). Plant species also have different affinities for $\mathrm{N}$, referred to as nitrophily, and can therefore be ranked along an oligotrophic-nitrophilic gradient. The most oligotrophic species are commonly found in N-limited soils (Ellenberg 1974) and have a poor growth response to soil $\mathrm{N}$ availability (Moreau et al. 2013). These differences in nitrophily between species are associated with functional differences involving a trade-off between species with a preferential allocation of carbon to root structure (i.e., root biomass) for the most oligotrophic species while carbon is preferentially allocated to root activity (i.e., $\mathrm{N}$ uptake rate) for the most nitrophilic ones (Moreau et al. 2014). As such, plant species with different $\mathrm{N}$ nutritional strategies could be considered as good models for investigating the importance of N-related traits in plant-microbe interactions.

In this, study, our objective was to determine how plant-microbe interactions, particularly interactions between plants and $\mathrm{N}$-cycling microbes, were affected by plant traits related to $\mathrm{N}$ nutrition. For this purpose, 11 plant species were selected along an oligotrophicnitrophilic gradient, and were grown individually in a $\mathrm{N}$ poor soil with two $\mathrm{N}$ treatments: 0 and $14 \mathrm{mmol} / \mathrm{L}$ of nitrate. Plant traits involved in plant $\mathrm{N}$ and carbon nutrition were measured as they are intrinsically linked. The genetic structure and abundance of rhizosphere microbial communities involved in $\mathrm{N}$-cycling (nitrate reducers and ammonia oxidizers) were analyzed. We hypothesized that plant traits related to $\mathrm{N}$ uptake play a key role in plant-microbe interactions and that soil $\mathrm{N}$ availability plays an important role in these interactions.

\section{Materials And Methods}

\section{Plant material and cultural conditions}

A greenhouse experiment was conducted in Dijon (France) using 11 monocotyledonous and dicotyledonous annual plant species (Table 1; see Plate 1). Seven weed and two crop species were selected to cover a gradient of nitrophily (Ellenberg 1974, Moreau et al. 2013, 2014). Medicago truncatula (Cook 1999) and Brachypodium distachyon (Draper et al. 2001) were also included as model species for genetics and genomics. Seeds were germinated in an incubator with a photoperiod of $12 \mathrm{~h}$, with day and night temperatures of $25^{\circ} \mathrm{C}$ and $15^{\circ} \mathrm{C}$, respectively. Thereafter, a single germinated seed was sown into 1-L pots. The plants were grown 
with either $0 \mathrm{mmol} / \mathrm{L}$ or $14 \mathrm{mmol} / \mathrm{L}$ of $\mathrm{N}$ provided in the form of nitrate. Thirteen plants were grown for each combination of species and $\mathrm{N}$ treatment. Pots contained a silty clay loam soil (Mas d'Imbert, France) with physical and chemical characteristics determined as $11 \%$ sand, $51 \%$ silt, $38 \%$ clay, $\mathrm{pH}=8,14.5 \mathrm{~g} / \mathrm{kg}$ of organic carbon, $1 \mathrm{~g} / \mathrm{kg}$ of organic $\mathrm{N}$. This soil had a low mineral $\mathrm{N}$ content $\left(0.018 \mathrm{~g} / \mathrm{kg} \mathrm{NO}_{3}{ }^{-}\right.$and $0.002 \mathrm{~g} / \mathrm{kg}$ of $\left.\mathrm{NH}_{4}{ }^{+}\right)$, making it possible to manipulate the soil $\mathrm{N}$ content. An $\mathrm{N}$-free nutrient solution was made up of $2.4 \mathrm{mmol} / \mathrm{L}$ $\mathrm{K}_{2} \mathrm{HPO}_{4}, 2.0 \mathrm{mmol} / \mathrm{L} \mathrm{MgSO} 4+7 \mathrm{H}_{2} \mathrm{O}, 5.0 \mathrm{mmol} / \mathrm{L}$ $\mathrm{CaCl}_{2}, 1.4 \mathrm{mmol} / \mathrm{L} \mathrm{K}_{2} \mathrm{SO}_{4}$, and $0.2 \mathrm{mmol} / \mathrm{L} \mathrm{NaCl}$. An $\mathrm{N}$-rich nutrient solution was made up of $5.35 \mathrm{mmol} / \mathrm{L}$ $\mathrm{KNO}_{3}, 0.2 \mathrm{mmol} / \mathrm{L} \mathrm{K}_{2} \mathrm{HPO}_{4}, 4.0 \mathrm{mmol} / \mathrm{L} \mathrm{Ca}\left(\mathrm{NO}_{3}\right)_{2}+4$ $\mathrm{H}_{2} \mathrm{O}, 0.33 \mathrm{mmol} / \mathrm{L} \mathrm{Mg}\left(\mathrm{NO}_{3}\right)_{2}+6 \mathrm{H}_{2} \mathrm{O}, 0.90 \mathrm{mmol} / \mathrm{L}$ $\mathrm{KH}_{2} \mathrm{PO}_{4}, 0.75 \mathrm{mmol} / \mathrm{L} \mathrm{MgSO}_{4}$, and $0.20 \mathrm{mmol} / \mathrm{L} \mathrm{NaCl}$. For both solutions, $\mathrm{pH}$ was adjusted to 6.5 . The nutrient solutions were dispensed by watering the pots automatically. Soil moisture was adjusted on a daily basis to soil water capacity. Additional light was supplied by sodium lamps (MACS 400 W, Mazda, Schenectady, New York, USA) to obtain a constant photoperiod of $14 \mathrm{~h}$. Air temperature (PT100 sensors; Pyro-Contrôle, Vaulx-enVelin, France) and incident photosynthetically active radiation (PAR; silicium sensors; Solems, Palaiseau, France) measurements were taken every $600 \mathrm{~s}$ and stored in a data logger (DL2e; Delta-T Devices, Cambridge, $\mathrm{UK})$. The air temperature was $18.2^{\circ} \pm 3.0^{\circ} \mathrm{C}($ mean \pm 1 SD), and the incident PAR was $11.3 \pm 0.6 \mathrm{~mol} \cdot \mathrm{m}^{-2} \cdot \mathrm{d}^{-1}$ (mean $\pm 1 \mathrm{SD})$. Two destructive measurements were performed at 56 and 77 days after sowing. On each of these sampling dates, five plants were sampled for each combination of species and $\mathrm{N}$ treatment $(n=5$ plants per species and $\mathrm{N}$ treatment).

\section{Microbial measurements}

The rhizosphere soil was sampled 56 days after sowing, after manually separating the root system with adhering soil from the pots. The rhizosphere soil was obtained by washing the root system in $50 \mathrm{~mL}$ of sterile distilled water with agitation (vortex at $30 \mathrm{~Hz}$ for $1 \mathrm{~min}$ ). The root system was discarded and the soil was collected after centrifugation at $9000 \mathrm{~g}$ for $10 \mathrm{~min}$. Each sample was stored at $-20^{\circ} \mathrm{C}$ before DNA extraction. The DNA extraction procedure was based on chemical and mechanical extraction as described by Mougel et al. (2006). Automated RISA fingerprinting was performed by amplifying the bacterial ribosomal IGS with primers S-D-Bact-1522-b-S-20 (3' end of $16 \mathrm{~S}$ genes) and L-DBact-132-a-A-18 ( $5^{\prime}$ end of 23S genes) (Normand et al. 1996) for bacterial automated ribosomal intergenic spacer analysis (B-ARISA). The PCR conditions, PCR template preparation for DNA sequencer loading, and electrophoresis conditions were as described by Ranjard et al. (2003).

The abundances of the total bacterial and crenarcheal communities, the bacterial and Thaumarchaeal ammonia oxidizers, and the nitrate reducers were determined by quantitative PCR (qPCR) as previously described (López-Gutiérrez et al. 2004, Leininger et al. 2006, Bru et al. 2007, Tourna et al. 2008). The small ribosomal subunit gene (16S rRNA) and the genes encoding the key enzymes catalyzing ammonia oxidation in bacteria (AOB) and Thaumarchaea (AOA) and nitrate reduction (nar $G$ and nap $A$ ) were used as molecular markers. The reactions were carried out in an ABI prism 7900 Sequence Detection System (LifeTechnologies, Carlsbad, California, USA). Quantification was based on the increase in fluorescence intensity of the SYBR Green dye during amplification. The real-time PCR assay was carried out in a $20-\mu \mathrm{L}$ reaction volume containing the SYBR green PCR Master Mix (Absolute QPCR SYBR Green Rox Thermo, Courtaboeuf, France), $1 \mu \mathrm{mol} / \mathrm{L}$ of each primer, $100 \mathrm{ng}$ of T4 gene 32 (MP Biomedicals, Illkirch, France), and 0.5 to $2 \mathrm{ng}$ of DNA. Two independent quantitative PCR assays were performed for each gene. Standard curves were obtained using serial dilutions of linearized plasmids containing the studied genes. The PCR efficiency for the various assays ranged between 83 and $100 \%$. Two to three no-template controls were run for each quantitative PCR assay and the no-template controls gave zero or negligible values. The presence of PCR inhibitors in the DNA extracted from the soil was estimated by mixing a known amount of standard DNA with soil DNA extract or water prior to qPCR. The measured cycle threshold $(\mathrm{Ct})$ values obtained for the various DNA extracts and the controls with water were not significantly different, indicating that there was no inhibition.

\section{Plant measurements}

At both sampling dates, four functional traits were measured on each plant: plant leaf area (LI-3100 Area Meter, LI-COR, Lincoln, Nebraska, USA), shoot and root biomass (determined after drying for $48 \mathrm{~h}$ at $80^{\circ} \mathrm{C}$ ), and the amount of $\mathrm{N}$ in the whole plant comprising both shoots and roots (Dumas procedure; Dumas 1831). In addition, the projected plant area was estimated every week for three consecutive weeks, starting 56 days after sowing, for three plants for each combination of species and $\mathrm{N}$ treatment. The projected leaf area was estimated non-destructively from photographs of individual plants taken with a top view camera. The photographs were analyzed using semi-automatic image analysis (Mathey et al. 2011, Moreau et al. 2013) to estimate the projected plant area for each plant. This total projected plant area was considered as a proxy of the area of the plant exposed to direct radiation.

The plant leaf area measured at the second sampling date was used to calculate the nitrophily index for each species as the ratio of leaf area at high soil $\mathrm{N}$ to leaf area at low soil N (Moreau et al. 2013). In addition, four other traits were calculated to account for the capacity of the plants to capture and use carbon and $\mathrm{N}$ resources (Moreau et al. 2014) between sampling dates 1 and 2, as follows: 
Radiation use efficiency (RUE, $\mathrm{g}$ of biomass/MJ of intercepted PAR) was calculated as:

$$
\mathrm{RUE}=\frac{(\mathrm{PB} 2-\mathrm{PB} 1)}{\Sigma \mathrm{IR}}
$$

where $\mathrm{PB}$ is whole-plant biomass including shoots and roots (g/plant), 1 and 2 refer to the sampling dates, and $\Sigma$ IR is the sum of intercepted PAR during this period (MJ/plant). Light interception was calculated as the product of leaf area and incident radiation (Granier and Tardieu 1999). The sum of daily intercepted PAR during the period between the two sampling dates was calculated as $\Sigma \mathrm{IR}=\sum_{i=1}^{D} \mathrm{PA} i \times \mathrm{PAR} i$, where $D$ is the day during the period, PA $i$ is projected area on day $i$ $\left(\mathrm{cm}^{2} /\right.$ plant) and PAR $i$ is the incident PAR on day $i$ $\left(\mathrm{MJ} \cdot \mathrm{m}^{-2} \cdot \mathrm{d}^{-1}\right)$. PA $i$ was calculated by interpolation after modeling the change in the measured projected leaf area with time using a sigmoid logistic curve (Debouche 1979).

Root weight ratio (RWR, g of root biomass/g of plant biomass) was calculated as:

$$
\mathrm{RWR}=\frac{(\mathrm{RB} 2-\mathrm{RB} 1)}{(\mathrm{PB} 2-\mathrm{PB} 1)}
$$

where RB is root biomass ( $\mathrm{g} / \mathrm{plant}$ ).

$\mathrm{N}$ uptake efficiency (NUE, $\mathrm{g}$ of $\mathrm{N}$ per $\mathrm{g}$ of root biomass per day) was calculated as:

$$
\mathrm{NUE}=\frac{(\mathrm{PN} 2-\mathrm{PN} 1)}{\Sigma \mathrm{RB}}
$$

where $\mathrm{PN}$ is the amount of $\mathrm{N}$ in the whole plant $(\mathrm{g} /$ plant) and $\Sigma \mathrm{RB}$ is the cumulated daily root biomass (g/ plant). Daily root biomass was calculated as a constant daily increase of root biomass calculated as (RB2 $\mathrm{RB} 1) / 21$, where 21 is the number of days between sampling dates.

Morphogenetic efficiency (ME, $\mathrm{cm}^{2}$ of leaf area/g of N) was calculated as:

$$
\mathrm{ME}=\frac{(\mathrm{LA} 2-\mathrm{LA} 1)}{(\mathrm{PN} 2-\mathrm{PN} 1)}
$$

where LA is the leaf area $\left(\mathrm{cm}^{2} /\right.$ plant $)$.

\section{Statistical analyses}

Principal component analysis (PCA) and between group analysis (BGA), a multivariate analysis method derived from PCA (Dolédec and Chessel 1987), were performed on the genetic structure data of bacterial communities associated with the rhizosphere for all combinations of the plant species and $\mathrm{N}$ treatments. Unlike PCA, BGA is a classification method: groups of samples are defined before the analysis run and BGA looks for functions that best separate the groups. A Monte Carlo test (multivariate permutation test) was used after BGA to check the significance of the differences between groups. Calculations were carried out and graphs were produced using the free ade4 package for R (Thioulouse et al. 1997). The effect of the plant species, the $\mathrm{N}$ treatment, and their combinations on the genetic structure of bacterial communities were tested as described by Zancarini et al. (2012).

Two-way analysis of variance (ANOVA) was performed to assess the effects of the plant species, $\mathrm{N}$ treatment, and interaction on the plant trait values and abundances of the microbial communities.

The correlation between the abundance of the functional microbial communities and plant traits was analyzed independently for each $\mathrm{N}$ treatment using Pearson correlation coefficients and the Holm method (Aickin and Gensler 1996). Correlations were analyzed in four steps for each $\mathrm{N}$ treatment: (1) abundances of $\mathrm{N}$ cycling microbial communities vs. NUE, (2) abundances of total bacteria and Crenarchaea vs. NUE, (3) abundance of $\mathrm{N}$ cycling vs. traits other than NUE, and (4) abundances of bacteria and Crenarchaea vs. traits other than NUE.

Significance was determined using $\alpha=0.05$ and analyses were performed using $\mathrm{R}$ x64 3.0.3 ( $\mathrm{R}$ Development Core Team 2014).

\section{Results}

\section{Plant traits}

At both sampling dates, the four plant traits describing plant growth (plant leaf area, shoot biomass, root biomass, and plant N) differed significantly between plant species and increased from low to high soil $\mathrm{N}$ supply in species-specific proportions. At the second sampling date (Fig. 1) for high soil N, there were significant differences in plant $\mathrm{N}$ between species, Brassica napus being about seven times higher than $B$. distachyon. Plant $\mathrm{N}$ increased from low-N to high-N soils from a factor of about three for the legume species M. truncatula to a factor of 59 for Geranium molle. The nitrophily index describing the response of plant growth to soil $\mathrm{N}$ availability varied significantly between plant species ranging from two for $M$. truncatula (the most oligotrophic species) to 38 for Matricaria perforata (the most nitrophilic species) (Table 1). These significant differences in plant growth traits between plant species and between $\mathrm{N}$ conditions were associated with significant differences in traits for plant carbon and $\mathrm{N}$ uptake and use (RUE, RWR, NUE, and ME; Fig. 2). The greatest differences between species were for NUE at low $\mathrm{N}$, with a ratio of about 70 between Triticum aestivum (the lowest NUE) and $M$. truncatula (the highest NUE). Soil N had the greatest positive effect on NUE, but the effect depended on the plant species. For example, NUE for $M$. truncatula was the same in low-N conditions as high-N conditions, but for Teucrium botrys it was about 80 times higher in high- $\mathrm{N}$ conditions than in low$\mathrm{N}$ conditions. For RWR and ME, there were a few negative mean trait values that were not significantly different from zero. 

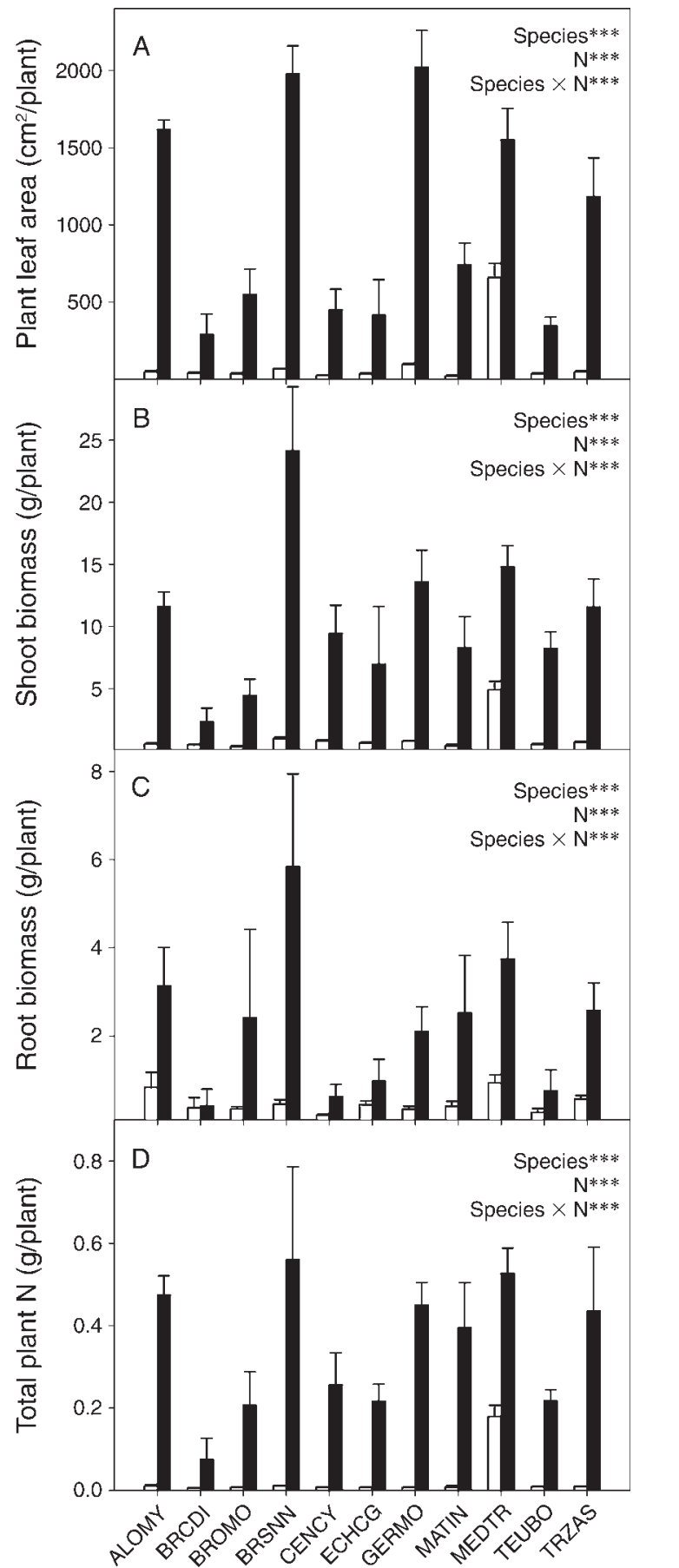

FIG. 1. Values (mean $+1 \mathrm{SE})$ at the second sampling date for traits describing plant growth of 11 species selected along an oligotrophic-nitrophilic gradient (but shown alphabetically here) and grown with low soil $\mathrm{N}$ (open bars) and high soil $\mathrm{N}$ (solid bars) availability. ANOVA results $(n=5$ plants for each combination of species and $\mathrm{N}$ treatments) for the significant main effects and interactions are shown as $* * * P<0.001$. See Table 1 for full scientific names by species code.
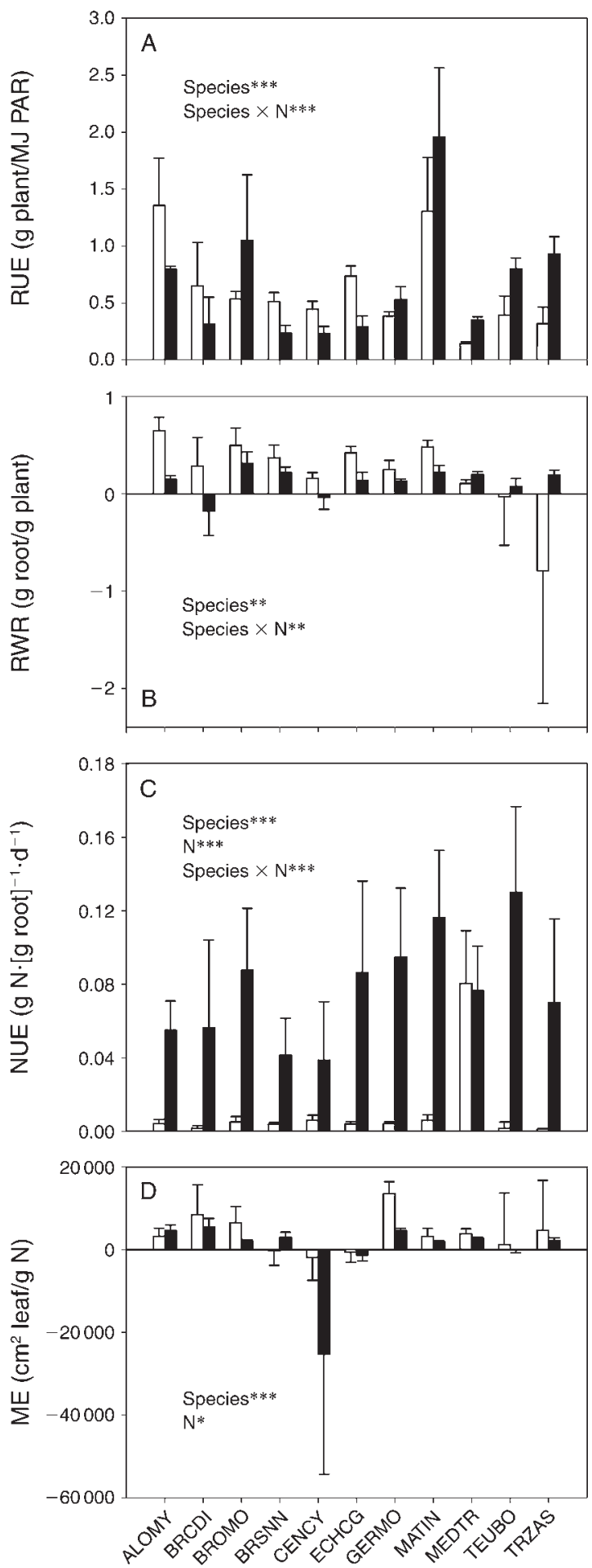

FIG. 2. Values (mean $+1 \mathrm{SE}$ ) for plant traits describing carbon and $\mathrm{N}$ uptake and use for the species grown with low soil $\mathrm{N}$ (open bars) and high soil $\mathrm{N}$ (solid bars): (A) radiation use efficiency, RUE, where PAR is photosynthetic active radiations; (B) root weight ratio, RWR; (C) N uptake efficiency, NUE; and (D) morphogenetic efficiency, ME. Significant main effects and interactions from ANOVA $(n=5$ plants for each combination of species and $\mathrm{N}$ treatments) are given as $* P<0.05$; ** $P<0.01$; $* * * P<0.001$. See Table 1 for full scientific names by species code. 

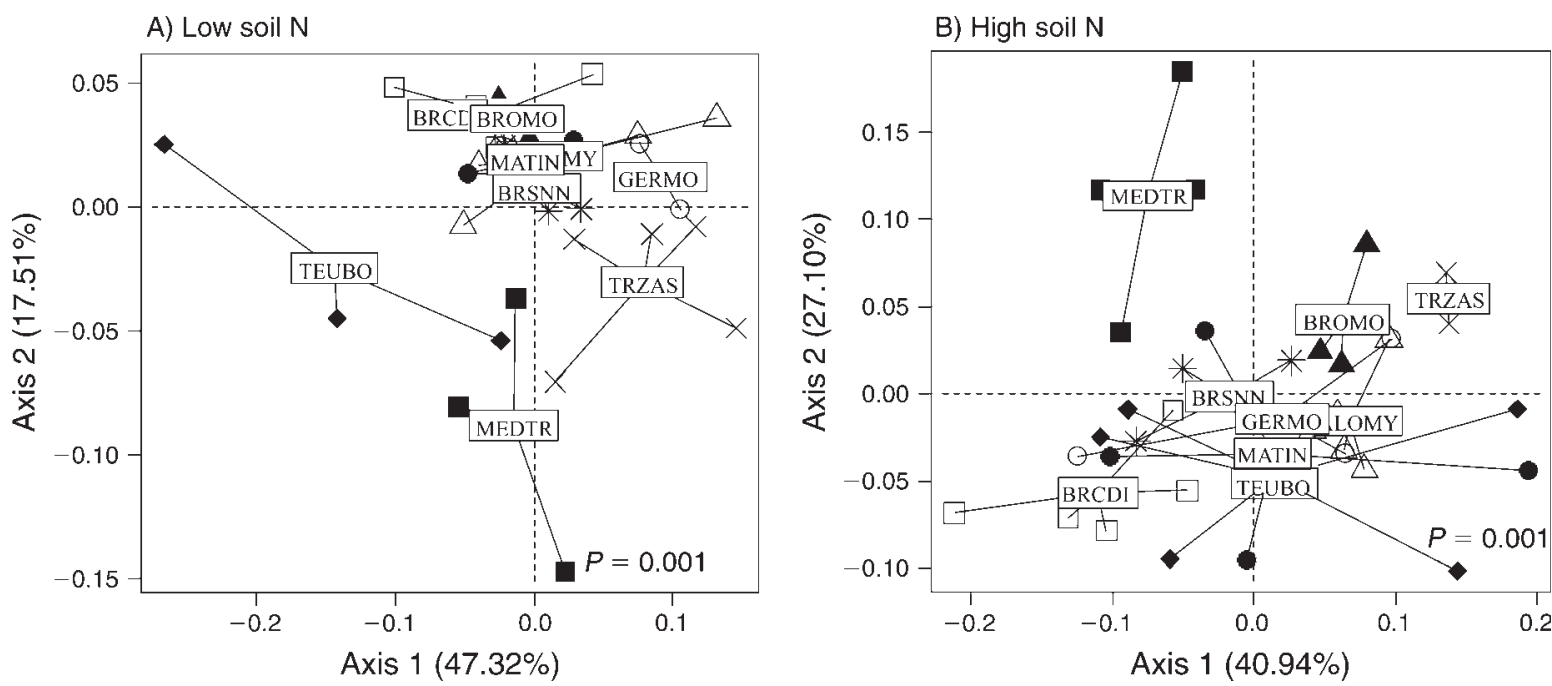

FIG. 3. Between-group analysis describing the structure of the rhizosphere bacterial communities of the plant species $(n=5$ plants per species) grown with (A) low soil N and (B) high soil N. Plant species: TEUBO (solid diamonds), BROMO (solid triangles), GERMO (open circles), ALOMY (open triangles), MATIN (solid circles), BRSNN (stars), TRZAS (crosses), BRCDI (open squares), and MEDTR (solid squares). We excluded Echinochloa crus galli from this analysis because its bacterial community was very different from that of all other plant species under both $\mathrm{N}$ treatments. Resolution of the RISA profiles of Centaurea cyanus L. was not sufficient for digital image analyses and the corresponding samples were therefore discarded. Values in parentheses in each axis label are the percentage of variation explained by that axis. See Table 1 for full scientific names by species code.

\section{Bacterial community structure and abundance of functional microbial communities}

The RISA data was analyzed by PCA to assess the effects of both plant species and soil $\mathrm{N}$ availability on rhizosphere bacterial communities. The RISA profiles of C. cyanus had a resolution that was too low for subsequent analyses and were therefore discarded. The first component of the PCA, which represented about $35 \%$ of the total variance, was principally explained by the interaction between plant species and $\mathrm{N}$ treatment $(P<0.001)$ while the second component was explained by the $\mathrm{N}$ treatment alone $(P=0.004)$. The RISA data obtained for low- and high-N treatments was analyzed by BGA separately. The two BGAs showed that the genetic structure of the rhizosphere bacterial communities was affected by plant species independent of soil $\mathrm{N}$ availability $(P<0.001$; see Appendix). Since the bacterial community in E. crus galli rhizosphere was very different from that of all the other plant species for both $\mathrm{N}$ treatments, a new BGA excluding E. crus galli was performed to assess the differences between the other plant species (Fig. 3). This showed significant differences in the rhizosphere bacterial communities for the other plant species. Moreover, the genetic structure of bacterial communities associated with the various plant species was different for the low $\mathrm{N}$ treatment and the high $\mathrm{N}$ treatment (Fig. 3). This result was confirmed by calculating the Euclidean similarity between both $\mathrm{N}$ treatments for each plant species showing that the bacterial genetic structure depended on $\mathrm{N}$ fertilization for all plant species (average value $\pm 1 \mathrm{SE}: 0.81 \pm 0.01$ ). The similarity was lowest for T. botrys $(0.70 \pm 0.03)$, indicating that the bacterial communities in $T$. botrys rhizosphere were more affected by the $\mathrm{N}$ treatment than those in the rhizosphere of the other plant species while $M$. truncatula had the highest similarity between $\mathrm{N}$ treatments.

As expected, the total bacterial community was largely predominant with $16 \mathrm{~S}$ rRNA copy numbers ranging from 3.3 to $6.1 \times 10^{5}$ numbers of copies per ng of DNA (Fig. 4). The Thaumarchaeal community was on average only about $5 \%$ of the bacterial community. The plant species had a significant effect on the abundance of microorganisms for all the communities studied except AOB (Fig. 4). The abundance of nitrate reducers carrying nap $A$ in the rhizosphere of $T$. botrys was, for example, about three times lower than that of $B$. napus at high soil N. Soil N availability affected the abundance of Crenarchaea, AOB, and AOA with a lower abundance at high $\mathrm{N}$ availability than at low soil $\mathrm{N}$ availability for each of these communities on average (Fig. 4).

\section{Relationships between plant traits and abundance of microbial communities}

The abundance of functional microbial communities was analyzed in relation to plant functional traits. All microbial communities except AOB were considered, as the plant species did not have any significant effect on the abundance of AOB. Plant traits describing plant growth (shoot and root biomass, plant $\mathrm{N}$, and plant leaf area) and the nitrophily index were not correlated with the abundance of microbial communities for either soil $\mathrm{N}$ treatment $(P>0.05)$. Of the traits describing carbon and $\mathrm{N}$ uptake and use (RUE, RWR, NUE, and ME), NUE was significantly negatively correlated with the 

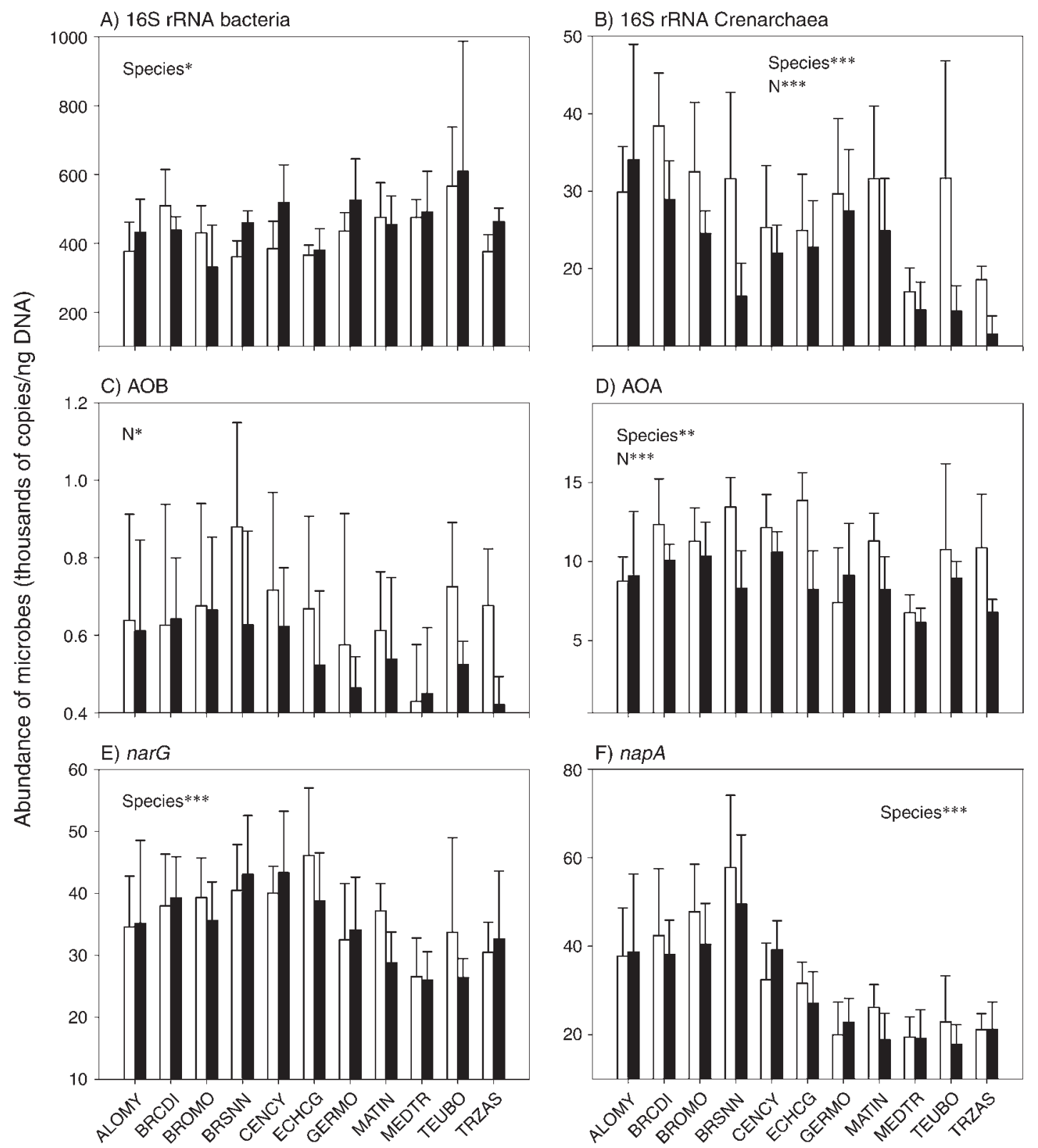

FIG. 4. Abundance of functional microbial communities with low soil N (open bars) and high soil N (solid bars). (A) 16S rRNA bacteria, (B) 16S rRNA Crenarchaea, (C) ammonia-oxidizing bacteria, AOB; (D) for Thaumarchaea, ammonia-oxidizing Archaea, AOA; (E) nar $G$-nitrate reducers, $n a r G ;(\mathrm{F})$ nap A-nitrate reducers, nap A. Significant main effects and interactions from ANOVA $(n$ $=5$ plants per species and $\mathrm{N}$ treatment) are given as $* P<0.05 ; * * P<0.01 ; * * * P<0.001$. Error bars show $+\mathrm{SD}$. See Table 1 for full scientific names by species code.

abundances of nap $A$ - and $n a r G$-nitrate reducers for high soil $\mathrm{N}$ availability (Fig. 5).

\section{Discussion}

Rhizosphere bacterial community structure is affected by soil $N$ availability and plant traits

The structure of the bacterial community in the rhizosphere was significantly different between plant species, which is in agreement with a large body of literature (Bardgett et al. 1999, Marschner et al. 2004). Of the species studied, E. crus galli exhibited the most different rhizosphere bacterial community compared to the other plant species in both $\mathrm{N}$ treatments. This result is probably linked to differences in photosynthesis as $E$. crus galli was the only $\mathrm{C}_{4}$ plant species in the study and $\mathrm{C}_{3}$ and $\mathrm{C}_{4}$ species have different carbon and $\mathrm{N}$ metabolisms (Greenwood et al. 1990), which is of importance for root exudation. 
More interesting, the results also indicate that the soil $\mathrm{N}$ level modulates the effect of the plant species on the structure of the bacterial community (Fig. 3). The differences in the structure of the bacterial community in the rhizosphere between $\mathrm{N}$ treatments were the highest for T. botrys, which was also the plant species with the highest differences in NUE between $\mathrm{N}$ treatments. $M$. truncatula had the least differences in the bacterial community and NUE between $\mathrm{N}$ treatments. Little attention has so far been paid to the contribution of $\mathrm{N}$ availability in shaping the microbial community composition in the rhizosphere. A recent study compared six different genotypes of M. truncatula and showed that the rhizosphere microbial community was affected not only by the plant genotype but also by $\mathrm{N}$ availability (Zancarini et al. 2012). This is in line with other studies showing shifts in the bacterial diversity in response to changes in the $\mathrm{N}$ availability (Nemergut et al. 2008, Fierer et al. 2011). Overall, these studies support our results, which suggest that plant traits, such as NUE, that affect $\mathrm{N}$ availability in the rhizosphere might also influence the structure of microbial communities. The importance of plant traits for microbial communities was recently demonstrated by de Vries et al. (2012), who showed that in addition to soil properties, communityweighted means of plant functional traits explained variations in microbial community composition.

\section{Competition for nitrate occurs between plants and nitrate-reducing bacteria}

At high $\mathrm{N}$ availability, there was a significant negative relationship between the abundance of nitrate-reducing bacteria within the total microbial community (expressed per narG and nap $A$ gene copy number per ng of soil DNA) and $\mathrm{N}$ uptake rates by plant roots (estimated by NUE; Fig. 5). In our study, nitrate was the main $\mathrm{N}$ source for plant growth as it was the only form of $\mathrm{N}$ provided. Nitrate is also of importance for nitrate-reducing bacteria since these microorganisms use $\mathrm{NO}_{\mathrm{X}}$ (e.g., nitrate and nitrite) as alternative electron acceptors when oxygen is limiting. Nitrate-reducing bacteria show a large taxonomic and physiological diversity (Philippot and Hojberg 1999) and as such, nitrate respiration is the only trait they share. Since the effect of plants on bacterial communities could only be detected at the functional gene level and was not observed when assessing the total bacterial abundance, we conclude that the interaction between the abundance of nitrate-reducing bacteria and $\mathrm{N}$ uptake rates by plants was direct and due to competition for nitrate between plant roots and nitrate-reducing bacteria. Such importance for bacteria of the ability to respire nitrate in the rhizosphere has previously been demonstrated by showing that a nitrate-reducing strain had a competitive advantage over an isogenic nitrate reductase deficientmutant in maize-planted soil (Ghiglione et al. 2002). This advantage has been attributed to the oxygenlimited conditions in the rhizosphere due to the

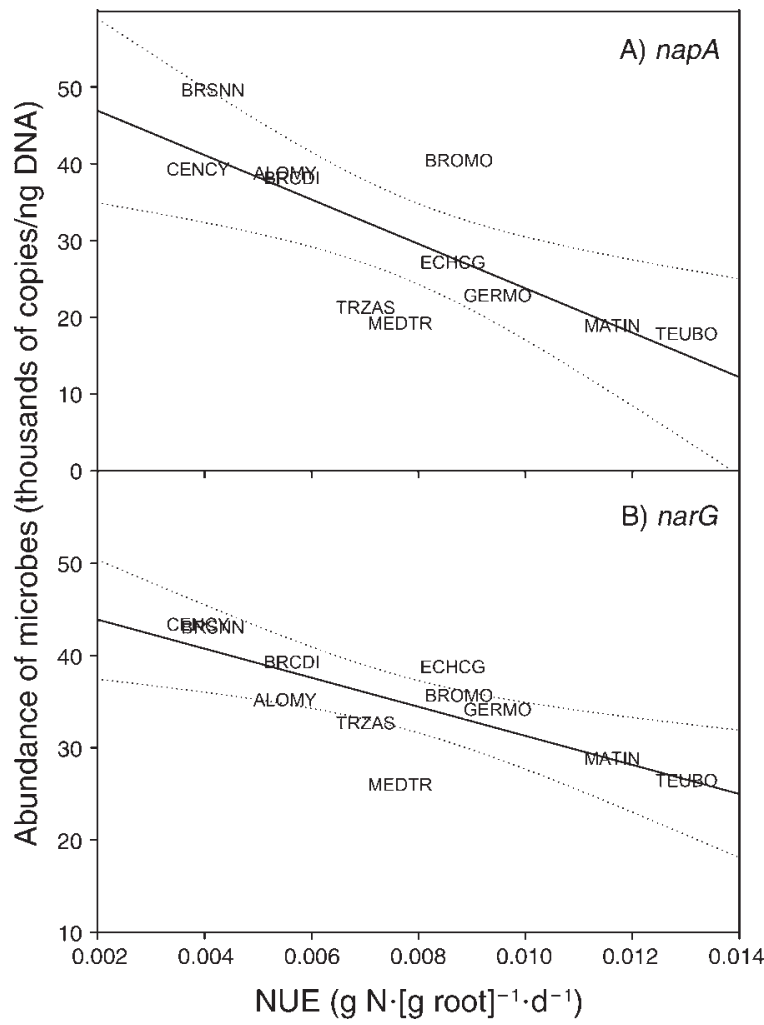

FIG. 5. Correlation between $\mathrm{N}$ uptake efficiency (NUE) by plant roots and abundance of (A) napA-nitrate reducing bacteria and (B) nar $G$-nitrate reducing bacteria. See Table 1 for full scientific names of species. Dotted lines indicate confidence intervals at $95 \%(n=5$ plants per species $)$. For nap $A, r=-0.76, P=0.0136$; for $n a r G, r=-0.76, P=0.0195$.

respiration of the plant roots and other rhizosphere microorganisms as well as to the release of carbon sources in the form of rhizodeposits (Philippot et al. 2009). In the low $\mathrm{N}$ treatment, NUE had no significant effect on the nitrate reducers suggesting that the nitrate availability was too limited to provide a competitive advantage for nitrate reducers over the other microorganisms. In addition, plant preference for $\mathrm{N}$ forms (nitrate, ammonium, or organic $\mathrm{N}$ ) depends on $\mathrm{N}$ availability (Britto and Kronzucker 2013). Thus, in Nlimited environments, plants can directly acquire amino acids and peptides released during the breakdown of organic matter (Näsholm et al. 1998, Jones et al. 2005, Näsholm et al. 2009). Therefore, some plant species may have shifted to sources of $\mathrm{N}$ other than nitrate at low $\mathrm{N}$ levels, reducing competition with nitrate-reducing bacteria.

We further expected that the nitrophily index would be a good predictor of plant-microbe interactions. Instead, most microbial variables that we measured were unresponsive to the nitrophily index, leaving our hypothesis unsupported. The fact that soil microbial guilds were significantly affected by NUE rather than nitrophily could be explained by the fact that the 


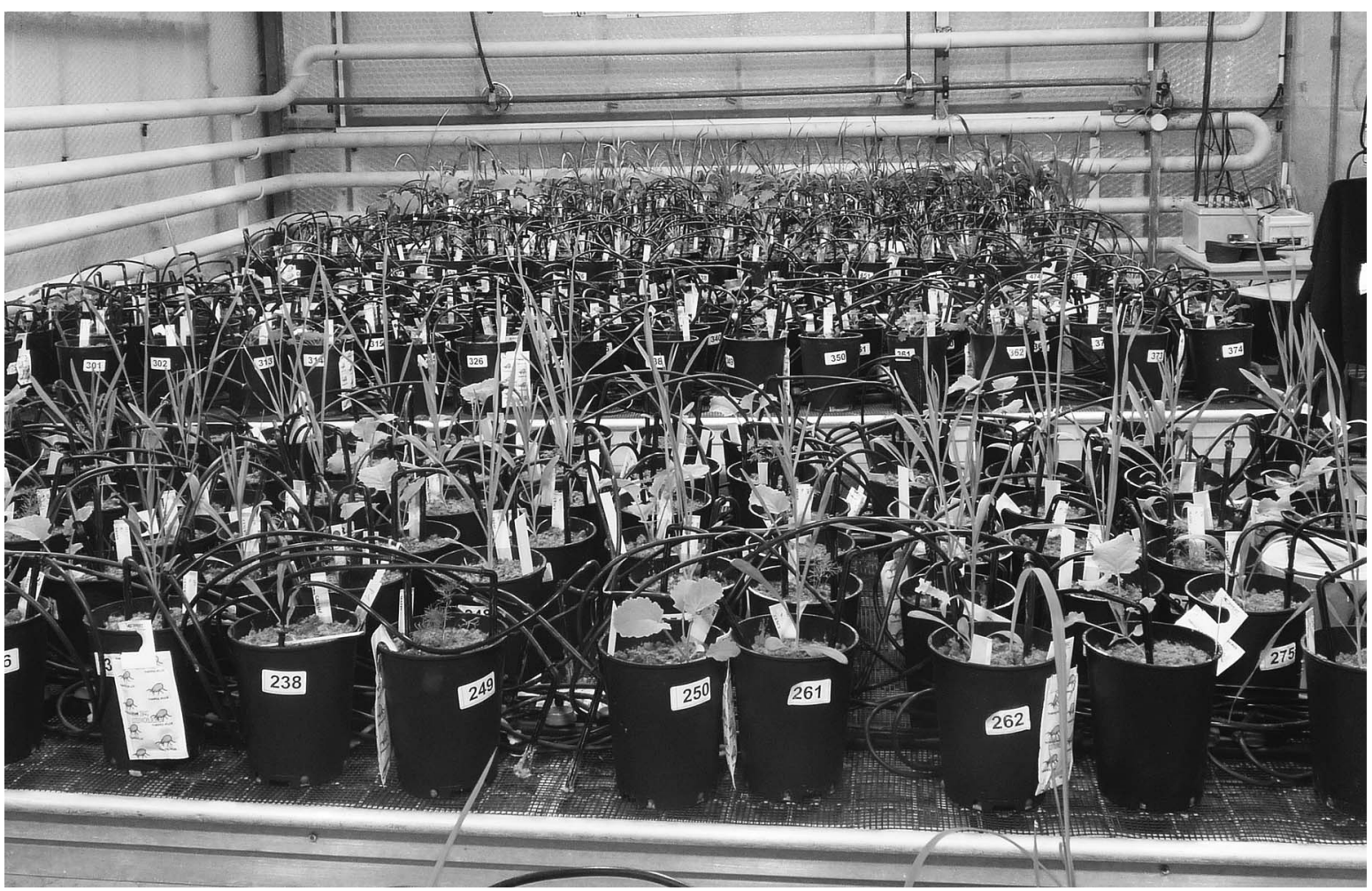

Plate 1. The greenhouse experiment conducted on eleven monocotyledonous and dicotyledonous plant species. Photo credit: A. Matejicek.

nitrophily index is a composite trait combining a set of ecophysiological processes (Moreau et al. 2014), whereas NUE is a trait quantifying the $\mathrm{N}$ uptake process. The results indicate that the microbial traits studied were related to plant traits associated with a specific ecophysiological process rather than to plant traits combining a number of processes.

Because microorganisms have a higher capacity for $\mathrm{N}$ uptake than plants (Kuzyakov and $\mathrm{Xu}$ 2013), they were expected to be more successful at $\mathrm{N}$ acquisition in the rhizosphere. However, a recent study showed that increasing $\mathrm{N}$ uptake rates by plants decreased microbial turnover due to a higher $\mathrm{N}$ limitation (Blagodatskaya et al. 2014). Similarly, Jensen and Nybroe (1999) described the plant rhizosphere as an environment with restricted $\mathrm{N}$ availability for microorganisms. In contrast to previous works studying the effect of plants on the total microbial community, i.e., mainly microorganisms assimilating $\mathrm{N}$ to convert it into $\mathrm{N}$-containing organic biomolecules in the same way as plants, this study focused on microbial guilds able to convert nitrate into other inorganic $\mathrm{N}$ forms to produce energy. Although we did not find any significant response of the total bacterial and Thaumarchaeal communities or the ammonia oxidizers to the plant traits measured, this study demonstrated that nitrate-reducing microorganisms can be negatively affected by plants with a higher NUE. This suggests that microorganisms using $\mathrm{N}$ forms as electron acceptors rather than for making biomass, suffer more from competition for resources with plants. Detrimental effects of a few plant species on $\mathrm{N}$-cycling microorganisms have been reported but the presence of inhibitory compounds within the plant exudates rather than traits related to the plant $\mathrm{N}$ nutrition was responsible for lower abundance or activity of the nitrifiers and denitrifiers (Subbarao et al. 2009, Dassonville et al. 2011). To our knowledge, this is the first study linking plant and microbial N-related traits for understanding plant-microbe interactions.

\section{Conclusions}

Whereas carbon is commonly considered as the main driver of plant-microbe interactions, this study puts forward the role of $\mathrm{N}$ in these interactions. We found that the influence of plant species on the bacterial community composition depended on $\mathrm{N}$ availability, which has several implications for agro-ecosystems amended regularly with $\mathrm{N}$ fertilizers. The results also provide an initial insight into the role N-related traits of both plants and microbes in plant-microbe interactions by showing that increasing plant $\mathrm{N}$ uptake rates adversely affected the abundance of nitrate-reducing microorganisms. Similarly, plant $\mathrm{N}$ uptake rates were related to differences in the composition of the microbial community in the rhizosphere. However, differences in the microbial communities studied were explained only 
by plant traits such as NUE, quantifying an ecophysiological process rather than by composite traits such as nitrophily. Future research should be undertaken to provide a more thorough understanding of the $\mathrm{N}$ forms that are assimilated by plants to explain the relationships between plant $\mathrm{N}$ uptake and the microbial communities involved in $\mathrm{N}$ cycling.

\section{ACKNOWLEDGMENTS}

This work was funded by the Plant Health and Environment division of the French National Institute for Agricultural Research (INRA). The authors are grateful to Lucie Laine and the greenhouse staff for their technical assistance, as well as Fabrice Dessaint and Anouk Zancarini for their help in statistical analyses.

\section{Literature Cited}

Aickin, M., and H. Gensler. 1996. Adjusting for multiple testing when reporting research results: the Bonferroni vs Holm methods. American Journal of Public Health 86:726-728.

Aira, M., M. Gomez-Brandon, C. Lazcano, E. Baath, and J. Dominguez. 2010. Plant genotype strongly modifies the structure and growth of maize rhizosphere microbial communities. Soil Biology and Biochemistry 42:2276-2281.

Bardgett, R. D., J. L. Mawdsley, S. Edwards, P. J. Hobbs, J. S. Rodwell, and W. J. Davies. 1999. Plant species and nitrogen effects on soil biological properties of temperate upland grasslands. Functional Ecology 13:650-660.

Baxendale, C., K. H. Orwin, F. Poly, T. Pommier, and R. D. Bardgett. 2014. Are plant-soil feedback responses explained by plant traits? New Phytologist 204:408-423.

Berg, G., and K. Smalla. 2009. Plant species and soil type cooperatively shape the structure and function of microbial communities in the rhizosphere. FEMS Microbiology Ecology 68:1-13.

Bezemer, T. M., C. S. Lawson, K. Hedlund, A. R. Edwards, A. J. Brook, J. M. Igual, S. R. Mortimer, and W. H. Van Der Putten. 2006. Plant species and functional group effects on abiotic and microbial soil properties and plant-soil feedback responses in two grasslands. Journal of Ecology 94:893-904.

Blagodatskaya, E., J. Littschwager, M. Lauerer, and Y. Kuzyakov. 2014. Plant traits regulating N capture define microbial competition in the rhizosphere. European Journal of Soil Biology 61:41-48.

Bouasria, A., T. Mustafa, F. De Bello, L. Zinger, G. Lemperiere, R. A. Geremia, and P. Choler. 2012. Changes in root-associated microbial communities are determined by species-specific plant growth responses to stress and disturbance. European Journal of Soil Biology 52:59-66.

Bremer, C., G. Braker, D. Matthies, A. Reuter, C. Engels, and R. Conrad. 2007. Impact of plant functional group, plant species, and sampling time on the composition of nirK-Type denitrifier communities in soil. Applied and Environmental Microbiology 73:6876-6884.

Britto, D. T., and H. J. Kronzucker. 2013. Ecological significance and complexity of $\mathrm{N}$-source preference in plants. Annals of Botany 112:957-963.

Bru, D., A. Sarr, and L. Philippot. 2007. Relative abundances of proteobacterial membrane-bound and periplasmic nitrate reductases in selected environments. Applied and Environmental Microbiology 73:5971-5974.

Cook, D. R. 1999. Medicago truncatula - a model in the making!: commentary. Current Opinion in Plant Biology 2: 301-304.

Dassonville, N., N. Guillaumaud, F. Piola, P. Meerts, and F. Poly. 2011. Niche construction by the invasive Asian knotweeds (species complex Fallopia): impact on activity, abundance and community structure of denitrifiers and nitrifiers. Biological Invasions 13:1115-1133.

De Deyn, G. B., H. Quirk, Z. Yi, S. Oakley, N. J. Ostle, and R. D. Bardgett. 2009. Vegetation composition promotes carbon and nitrogen storage in model grassland communities of contrasting soil fertility. Journal of Ecology 97:864-875.

de Vries, F. T., et al. 2012. Abiotic drivers and plant traits explain landscape-scale patterns in soil microbial communities. Ecology Letters 15:1230-1239.

Debouche, C. 1979. Présentation coordonnée de différents modèles de croissance. Revue de Statistique Appliquée 27:522.

Dolédec, S., and D. Chessel. 1987. Rythmes saisonniers et composantes stationnelles en milieu aquatique. I: description d'un plan d'observation complet par projection de variables. Acta oecologica. Oecologia Generalis 8:403-426.

Draper, J., L. A. J. Mur, G. Jenkins, G. C. Ghosh-Biswas, P. Bablak, R. Hasterok, and A. P. M. Routledge. 2001. Brachypodium distachyon. A new model system for functional genomics in grasses. Plant Physiology 127:1539-1555.

Dumas, J. B. A. 1831. Procédés de l'analyse organique. Annales de Chimie et de Physique 247:198-213.

Ellenberg, H. 1974. Zeigerwerte der gefässpflanzen mitteleuropas. Scripta geobotanica 9:1-97.

Fierer, N., C. L. Lauber, K. S. Ramirez, J. Zaneveld, M. A. Bradford, and R. Knight. 2011. Comparative metagenomic, phylogenetic and physiological analyses of soil microbial communities across nitrogen gradients. The ISME Journal 6: $1007-1017$

Frank, D. A., and P. M. Groffman. 2009. Plant rhizospheric N processes: what we don't know and why we should care. Ecology 90:1512-1519.

Ghiglione, J. F., A. Richaume, L. Philippot, and R. Lensi. 2002. Relative involvement of nitrate and nitrite reduction in the competitiveness of Pseudomonas fluorescens in the rhizosphere of maize under non-limiting nitrate conditions. FEMS Microbiology Ecology 39:121-127.

Granier, C., and F. Tardieu. 1999. Leaf expansion and cell division are affected by reducing absorbed light before but not after the decline in cell division rate in the sunflower leaf. Plant, Cell and Environment 22:1365-1376.

Greenwood, D. J., G. Lemaire, G. Gosse, P. Cruz, A. Draycott, and J. J. Neeteson. 1990. Decline in percentage N of C3 and C4 crops with increasing plant mass. Annals of Botany 66: 425-436.

Hartmann, A., M. Rothballer, and M. Schmid. 2008. Lorenz Hiltner, a pioneer in rhizosphere microbial ecology and soil bacteriology research. Plant and Soil 312:7-14.

Hawkes, C. V., I. F. Wren, D. J. Herman, and M. K. Firestone. 2005. Plant invasion alters nitrogen cycling by modifying the soil nitrifying community. Ecology Letters 8:976-985.

Hiltner, L. 1904. Über neuere erfahrungen und probleme auf dem gebiete der bodenbakteriologie unter besonderer berücksichtigung der gründüngung und brache. Arbeiten der Deutschen Landwirtschaftlichen Gesellschaft 98:59-78.

Hodge, A., D. Robinson, and A. Fitter. 2000. Are microorganisms more effective than plants at competing for nitrogen? Trends in Plant Science 5:304-308.

Jensen, L. E., and O. Nybroe. 1999. Nitrogen availability to Pseudomonas fluorescens DF57 is limited during decomposition of barley straw in bulk soil and in the barley rhizosphere. Applied and Environmental Microbiology 65:4320-4328.

Jones, D. L., J. R. Healey, V. B. Willett, J. F. Farrar, and A. Hodge. 2005. Dissolved organic nitrogen uptake by plantsan important $\mathrm{N}$ uptake pathway? Soil Biology and Biochemistry $37: 413-423$.

Kuzyakov, Y., and X. Xu. 2013. Competition between roots and microorganisms for nitrogen: mechanisms and ecological relevance. New Phytologist 198:656-669.

Leininger, S., T. Urich, M. Schloter, L. Schwark, J. Qi, G. Nicol, J. Prosser, S. Schuster, and C. Schleper. 2006. Archaea 
predominate among ammonia-oxidizing prokaryotes in soils. Nature 442:806-809.

López-Gutiérrez, J. C., S. Henry, S. Hallet, F. Martin-Laurent, G. Catroux, and L. Philippot. 2004. Quantification of a novel group of nitrate-reducing bacteria in the environment by realtime PCR. Journal of Microbiological Methods 57:399-407.

Marschner, P., D. Crowley, and C. Yang. 2004. Development of specific rhizosphere bacterial communities in relation to plant species, nutrition and soil type. Plant and Soil 261:199208.

Mathey, P., D. Moreau, and N. Munier-Jolain. 2011. Standardisation de la prise de photographies en conditions contrôlées pour l'estimation non destructive de la surface foliaire. Le Cahier des Techniques de l'Inra 72:31-36.

Mendes, R., P. Garbeva, and J. M. Raaijmakers. 2013. The rhizosphere microbiome: significance of plant beneficial, plant pathogenic, and human pathogenic microorganisms. FEMS Microbiology Reviews 37:634-663.

Moreau, D., H. Busset, A. Matejicek, and N. Munier-Jolain. 2014. The ecophysiological determinants of nitrophily in annual weed species. Weed Research 54:335-346.

Moreau, D., G. Milard, and N. Munier-Jolain. 2013. A plant nitrophily index based on plant leaf area response to soil nitrogen availability. Agronomy for Sustainable Development 33:809-815.

Mougel, C., P. Offre, L. Ranjard, T. Corberand, E. Gamalero, C. Robin, and P. Lemanceau. 2006. Dynamic of the genetic structure of bacterial and fungal communities at different developmental stages of Medicago truncatula Gaertn. cv. Jemalong line J5. New Phytologist 170:165-175.

Näsholm, T., A. Ekblad, A. Nordin, R. Giesler, M. Hogberg, and P. Hogberg. 1998. Boreal forest plants take up organic nitrogen. Nature 392:914-916.

Näsholm, T., K. Kielland, and U. Ganeteg. 2009. Uptake of organic nitrogen by plants. New Phytologist 182:31-48.

Nemergut, D. R., et al. 2008. The effects of chronic nitrogen fertilization on alpine tundra soil microbial communities: implications for carbon and nitrogen cycling. Environmental Microbiology 10:3093-3105.

Normand, P., C. Ponsonnet, X. Nesme, M. Neyra, and P. Simonet. 1996. ITS analysis of prokaryotes. Pages 1-12 in D. Akkermans, J. Van Elsas, and E. De Bruijn, editors. Molecular microbial ecology manual. Kluwer, Amsterdam, The Netherlands.

Orwin, K. H., S. M. Buckland, D. Johnson, B. L. Turner, S. Smart, S. Oakley, and R. D. Bardgett. 2010. Linkages of plant traits to soil properties and the functioning of temperate grassland. Journal of Ecology 98:1074-1083.

Philippot, L., S. Hallin, G. Börjesson, and E. Baggs. 2009. Biochemical cycling in the rhizosphere having an impact on global change. Plant and Soil 321:61-81.

Philippot, L., and O. Hojberg. 1999. Dissimilatory nitrate reductases in bacteria. Biochimica et Biophysica Acta-Gene Structure and Expression 1446:1-23.

Philippot, L., J. M. Raaijmakers, P. Lemanceau, and W. H. van der Putten. 2013. Going back to the roots: the microbial ecology of the rhizosphere. Nature Reviews Microbiology 11: 789-799.

R Development Core Team. 2014. R: a language and environment for statistical computing. $\mathrm{R}$ Foundation for Statistical Computing, Vienna, Austria.

Ranjard, L., D. P. Lejon, C. Mougel, L. Schehrer, D. Merdinoglu, and R. Chaussod. 2003. Sampling strategy in molecular microbial ecology: influence of soil sample size on DNA fingerprinting analysis of fungal and bacterial communities. Environmental Microbiology 5:1111-1120.

Subbarao, G., et al. 2009. Evidence for biological nitrification inhibition in Brachiaria pastures. Proceedings of the National Academy of Sciences USA 106:17302-17307.

Subbarao, G., et al. 2012. Biological nitrification inhibition-a novel strategy to regulate nitrification in agricultural systems. Advances in Agronomy 114:249-302.

Thioulouse, J., D. Chessel, S. Dole, and J.-M. Olivier. 1997. ADE-4: a multivariate analysis and graphical display software. Statistics and Computing 7:75-83.

Tourna, M., T. E. Freitag, G. W. Nicol, and J. I. Prosser. 2008. Growth, activity and temperature responses of ammoniaoxidizing archaea and bacteria in soil microcosms. Environmental Microbiology 10:1357-1364.

Tsiknia, M., V. A. Tzanakakis, and N. V. Paranychianakis. 2013. Insights on the role of vegetation on nitrogen cycling in effluent irrigated lands. Applied Soil Ecology 64:104-111.

Van Der Heijden, M. G., R. D. Bardgett, and N. M. Van Straalen. 2008. The unseen majority: soil microbes as drivers of plant diversity and productivity in terrestrial ecosystems. Ecology Letters 11:296-310.

van der Heijden, M. G., J. N. Klironomos, M. Ursic, P. Moutoglis, R. Streitwolf-Engel, T. Boller, A. Wiemken, and I. R. Sanders. 1998. Mycorrhizal fungal diversity determines plant biodiversity, ecosystem variability and productivity. Nature 396:69-72.

Violle, C., M.-L. Navas, D. Vile, E. Kazakou, C. Fortunel, I. Hummel, and E. Garnier. 2007. Let the concept of trait be functional! Oikos 116:882-892.

Vitousek, P. M., and R. W. Howarth. 1991. Nitrogen limitation on land and in the sea: how can it occur? Biogeochemistry 13: $87-115$.

Yin, H. J., Z. F. Xu, Z. Chen, Y. Y. Wei, and Q. Liu. 2012. Nitrogen transformation in the rhizospheres of two subalpine coniferous species under experimental warming. Applied Soil Ecology 59:60-67.

Zancarini, A., C. Mougel, S. Terrat, C. Salon, and N. MunierJolain. 2013. Combining ecophysiological and microbial ecological approaches to study the interaction between Medicago truncatula genotypes and the soil microbial communities. Plant and Soil 365:183-199.

Zancarini, A., C. Mougel, A. S. Voisin, M. Prudent, C. Salon, and N. Munier-Jolain. 2012. Soil nitrogen availability and plant genotype modify the nutrition strategies of $M$. truncatula and the associated rhizosphere microbial communities. PLoS ONE 7:e47096.

\section{Supplemental Material}

\section{Ecological Archives}

The Appendix is available online: http://dx.doi.org/10.1890/14-1761.1.sm 